\title{
“...which, like his latest songs, might extend his name also within the wider circles of the artistic world": Zdeněk Fibich's Meluzína (op. 55 Hud. 187)
}

\section{Anja Bunzel}

As the first music journal to comment on Zdeněk Fibich's Meluzina, the journal Dalibor predicted in January 1873 that its success would help to spread Fibich's name within the "wider circles of the artistic world". ${ }^{1}$ In retrospect, this prediction might have been quite optimistic, as, up until this day, Fibich has been acknowledged primarily for his innovative approach to music-dramatic genres for the stage. ${ }^{2}$ While the orchestral score of Fibich's Meluzina was not published, its piano reduction appeared in print with the Prague publisher Urbánek in $1911 .^{3}$ The myth of a relationship between an earthly and an unearthly being was a popular theme during the Romantic and post-Romantic periods. There exist a number of nineteenth-century musical works bearing the same

1 For full quotation and bibliographical information see footnote 5 .

2 See, for instance, in chronological order: Vladimír Hudec, Fibichova cesta k scénickému melodrama (Prague, 1969); Jan Smaczny, “The Operas and Melodramas of Zdeněk Fibich (1850-1900)," Proceedings of the Royal Musical Association 109 (1982): 119-33; Gerald Abraham, "The Operas of Zdeněk Fibich,” 19th-Century Music 9, no. 2 (1985): 136-44; Jaroslav Jiránek, "Zdeněk Fibich: Mistr scénického melodramu a lyrické miniatury," Opus musicum 27, no. 2 (1995): 52-62; Jiří Kopecký, Opery Zdeňka Fibicha z devadesátých let 19. Století (Olomouc: Palacký University, 2008); many chapters in Zdeněk Fibich as a Central European Composer at the End of the Nineteenth Century (= Musicolologica Olomucensia 12), ed. Patrick F. Devine, Vladislava Kopecká and Jiří Kopecký (Olomouc: Palacký University, 2010); Věra Šustíková and Jana Fojtíková, Fibich - melodram - secese (Prague: ČHSSZF a NM-MČH, 2000); Máté Mesterházi, “Die Umwertung Der Idee Der Nationaloper Um 1900," Studia Musicologica 52, nos 1-4 (2011): 95-107; Ivana Rentsch, "Broučeks Prag: Die Opernästhetik Leoš Janáčeks und Ihre Wurzeln in Der Tschechischen Musikgeschichte," Archiv Für Musikwissenschaft, 71, no. 3 (2014): 167-90; Věra Šustíková, "Prameny k Fibichově melodramatickému cyklu Hippodamie (Výpověd’ o tvůrčím procesu a novátorském přínosu autora)," Opus musicum 46, no. 6 (2014): 48-61; Věra Šustíková, Zdeněk Fibich a český koncertni melodrama (Olomouc: Palacký University Press, 2014); Judith A. Mabary, Contextualizing Melodrama in the Czech Lands: In Concert and on Stage (London/New York: Routledge, 2021), especially chapters 6, 7 and 8.

3 Zdeněk Fibich, Melusina / Die Windsbraut: balada pro sola, smišený sbor a orchestr: Op. 55 (Prague: Urbánek, 1911). 
title, "Melusine”. Conradin Kreutzer's setting of Franz Grillparzer's Melusine was premiered in Berlin in 1833. Two years later, Felix Mendelssohn performed his own overture inspired by Kreutzer's opera in Leipzig, and Antonín Dvořák's Rusalka (1901), too, encompasses a similar theme. ${ }^{4}$ Unlike these compositions Fibich's work is not a stage work but a cantata-style ballad for soloists, mixed choir and orchestra. Furthermore, Fibich's setting is based on the words of the German revolutionary Gottfried Kinkel (1815-1882), although versions by more famous writers would have been available - for instance that of Grillparzer.

This article aims to shed light on Fibich's Meluzina from two perspectives: reception history and compositional aesthetics. First, I will show that the work was primarily praised for its onomatopoeic features by the contemporary press, thus emphasising punctual rather than large-scale conceptual compositional aesthetics. Moreover, I will thematise in this chapter that the musical press compared Fibich to his German predecessors, thus viewing him as a European composer, although the nature of criticism differed between the German- and Czech-language journals. Second, I devote some room to music-aesthetic considerations, thus granting Fibich's Meluzina analytical attention which it did not receive in its own time. In doing so, I will argue that Fibich's Meluzina is based on a complex overall formal plan, which enables the female protagonist, i.e., the giant's daughter, to take agency in places where she remains completely silent in the poem.

On January 10,1873, Dalibor announced the completion of Fibich's Meluzina and stated that:

\begin{abstract}
Zdeněk Fibich completed the great cantata Melusina (to words by Kinkel) for soli, mixed choir and orchestra, which, like his latest songs, might spread his name also within the world's wider artistic circles. The music corresponds so naturally and effectively to the Romantic expression of the poem that, without obviously interfering with the masters of the Romantic period, Mendelssohn, Schubert and Schumann, this work's great success can be predicted everywhere. ${ }^{5}$
\end{abstract}

This review shows that Fibich was viewed in the Czech-language media as a European composer equal to such predecessors as Felix Mendelssohn, Franz

\footnotetext{
Lesser-known composers who occupied themselves with the same subject include Louis Schindelmeisser (1861), Karl Grammar (1875), Karl Theodor Emanuel von Perfall (1881), and Emerik Beran (1896).

5 Dalibor 1, no. 2 (10 January 1873): 13. "Zdeněk Fibich dokončil velikou kantátu Meluzina (na slova Kinkla) pro soly, smíšený sbor a orkestr, kteráž jako nejnovější jeho písně,jméno jeho rozšíriti může i v širších kruzích světa uměleckého. Nalezli pro romantický výraz básně hudební mluvu tak přirozenou a zaroveň účinnou, aniž zjevně zavadil o mistry v oboru romantiky, Mendelssohna, Šuberta a Šumana, že věštiti lze jeho dílu všude úspěch skvělý."
} 
Schubert, and Robert Schumann. As an aside, this comparison is also interesting to the extent that both Mendelssohn and Schumann knew (of) Gottfried Kinkel, who penned the words to Fibich's Meluzina. Neither of them utilised any of his texts for a dramatic work, however. Mendelssohn had hoped to receive an opera libretto from Kinkel, which never materialised; Schumann, on the other hand, never set the words of Gottfried, or, indeed, his wife Johanna Kinkel, with the latter of whom he had professional encounters through his capacity as editor of the Neue Zeitschrift für Musik. ${ }^{6}$ In that regard, Fibich was quite unique in the sense that he chose to set the words of Kinkel rather than those of a betterknown librettist, playwright, or poet.

Anežka Schulzová, writing under the pseudonym of Carl Ludwig Richter, in her biography of Fibich, devoted three full pages to Meluzina, two and a half of which, however, are dedicated to a detailed synopsis of the poem, thus somehow foregrounding the words rather than the music. With regard to the latter, Schulzová stresses punctual expressive means portraying the individual characters and draws on Fibich's tone painting. She writes:

Fibich's musical interpretation of this rich poem incorporates many colours and it features a masterly, effective expressive character. An especially important role is assigned to the orchestra, which offered its richest means in order to portray the hissing and surging of the water, the flickering flame of the fire, the thundery arrival of the gnome, and the wild, unruly boom of the storm. The solo voices are no less important in creating this powerful effect, as they lend a voice to the emotional outbreaks of the giant's daughter and the characteristic chants of the wooers; as well as the choir, which takes on the narrator's role. Unfortunately, this compelling composition, which was penned as early as 1874 , has not been published yet. $^{7}$

6 On Mendelssohn and Kinkel and their communication regarding an opera libretto, see the letter from Johanna Kinkel to Felix Mendelssohn, dated Bonn, February 25, 1843 (unpublished, Oxford Bodleian Library, GB-Ob, M.D.M.d.43/100-101), and Felix's response to Johanna's letter dated 2 April 1843, published in Felix Mendelssohn Bartholdy: Sämtliche Briefe in 12 Bänden, ed. Helmut Loos and Wilhelm Seidel, volume 9, ed. Stefan Münnich, Lucian Schiwietz and Uta Wald (Kassel: Bärenreiter, 2015), 264-5. On Robert Schumann's relationship with Johanna Kinkel see Anja Bunzel, "Critical Responses to Nineteenth-Century Music Criticism: Johanna Kinkel's Trinklieder and Her Later Lieder Collectionsm," in Nineteenth-Century Music Criticism, ed. Teresa Cascudo (Turnhout: Brepols, 2017), 421-48 (esp. 426-30).

7 Carl Ludwig Richter, Zdenko Fibich: Eine musikalische Silhouette (Prague: Urbánek, 1900), 47. "Fibich's musikalische Darstellung dieses kontrastreichen Gedichtes schwelgt in blendenden Farben und ist von meisterhafter, packender Charakteristik. Eine besonders gewichtige Rolle ist dem Orchester zugetheilt, welches seine reichsten Mittel aufgeboten hat, um das Rauschen und Wogen des Wasserstromes, die flackernde Lohe des Feuers, die donnernde Ankunft des Gnomen und das wilde, unbändige Brausen des Sturmes zu veranschaulichen. An der mächtigen Wirkung nächst dem Orchester nicht minder betheiligt sind sowohl die Solostimmen, welche die 
Perhaps it is due to the lack of a published score that contemporary performances are difficult to trace and the work today is lesser-known than other works by Fibich, even though the contemporary press displayed an interest in the composition and its performance. In February 1874, Dalibor informs the reader that:

Zdeněk Fibich [...] intends to visit Prague on the occasion of his performance of his opera Bukovin, which is scheduled for next month. [...]. During his visit, he will bring with him the score of his excellent symphonic poem Záboj a Slavoj as well as the score of a great vocal composition (for choir and solo voices) with orchestra called Melusina and we hope that under favourable circumstances one or the other will be performed as a concert to the Prague public still in this season. ${ }^{8}$

This request did not come true for Meluzina. In his thematic catalogue Vladimír Hudec has shown that Meluzina was not premiered in Prague until more than two years later, on December 10,1876. ${ }^{9}$

The work was performed in Prague again on April 20, 1879 in a joint programme alongside Schumann's Manfred (to words by Byron) and Brahms's Schicksalslied (to words by Hölderlin) as a charity concert organised by the St Vitus Musical Association (Musikverein St. Vitus). Dalibor published a review of this performance, stating that the two pieces at the beginning would have already made a complete concert by themselves, but that the performance of the third piece, i.e. Fibich's Meluzina was the 'most successful one of the whole concert', because the singers performed well through to the end. ${ }^{10}$ Possibly due to Schumann's and Brahms's involvement in the programme, this performance received attention further afield and was reviewed in both Neue Zeitschrift für Musik and Montags-Revue aus Böhmen: Wochenschrift für Politik, Volkswirtschaft, Kunst und

leidenschaftlichen Ausbrüche der Riesentochter und die charakteristischen Gesänge der Freier bringen, wie auch der Chor, dem die Rolle des Erzählers zugewiesen ist. Leider harrt diese fesselnde Composition, welche bereits im Jahre 1874 verfasst wurde, bisher der Veröffentlichung."

8 “Zprávy z Prahy a z venkova”, Dalibor 2, no. 8 (21 February 1874): 61. "Zdeněk Fibich, nyní profesor hudby ve Vilně, hodlá navštíviti Prahu při př́ležitosti provedení své opery Bukovín, jež určeno jest na prríští měsíc. $V$ poslední době komponoval snažlivý a neunavný skladatel ten opět nový cyklus písní Ditmarových Klaus Grothe, jež vyznamenávají se vesměs jak skvělou stránkou čistě deklamační, tak i ozdobným podkladem průvodu klavírního a duchaplným uspořádáním celkovým. Při návštěvě své přinese sebou především partituru výtečné své symfonické básně Záboj a Slavoj i partituru velké vokální skladby (pro sbor a hlasy solové) s průvodem orkestru pod názvem Melusina i doufáme, že na příznivých okolností jedna či druhá skladba obecenstvu pražskému bude ještě v této saisoně koncertní předvedena."

9 Vladimír Hudec, Zdeněk Fibich: tematický katalog (Prague: Bärenreiter, 2001), 235-36.

10 Dalibor 1, no. 14 (10 May 1879): 112. "Provedení skladby té bylo poměrné nejzdařilejší z celého koncertu."The concert was announced in Dalibor on the day of the concert, but there are no hints at the music-compositional features of Fibich's Meluzina in the announcement. Dalibor 1, no. 12 (20 April 1879): 97. 
Literatur. ${ }^{11}$ Both journals speak less favourably of Fibich's composition. Following a short general praise of the association's achievements and artistic progress, the Prague correspondent of Neue Zeitschrift für Musik writes that:

The association programmed in their second concert this year on April 20 under the directorship of Ludwig Procházka [...] Schumann's music to Byron's Manfred, the Schicksalslied by Brahms, a musically highly-interesting rendering of Hölderlin's great poem in the classical-hellenian spirit, Hyperions Schicksalslied, and Die Windsbraut, ballad by Zdenko Fibich for soli, choir, and orchestra. Although the latter features some felicitous passages full of musical talent, it lacks strength and power, indeed characteristics, which would have been necessary in order to grapple with such a difficult task. Furthermore, we cannot comprehend why Fibich decided to base his composition on such a weak Czech reworking of the powerful, poetically complete ballad by Kinkel; it is a mistake which has taken revenge on him now. ${ }^{12}$

The review published in the Montags-Revue aus Böbmen is much longer, but the section on Fibich's Meluzina seems similarly unenthusiastic as the one cited previously:

[...], the third and last number of the programme, the musical painting Die Windsbraut for soli, choir, and orchestra by Zd. Fibich had a difficult standing. Not only had the duration of the previous two numbers claimed the attention of

11 Vlasta Reittererová and Viktor Velek mention another, much later performance of Fibich's $M e$ luzina in their examination of the Viennese reception of Fibich's works: Vlasta Reittererová and Viktor Velek, "Wien um 1900 und die Wiener Rezeption der Werke von Zdeněk Fibich,” Musicologica Olomucensia 12 (December 2010): 17-62 (58).

12 “Correspondenzen, Prag," Neue Zeitschrift für Musik 75, no. 40 (26 September 1879): 406. “Der Musikverein St Veit hat sich in der kurzen Zeit seines Bestehens bedeutende Verdienste um die Förderung des öffentliche Musikpflege bei uns erworben, die jeder Musikfreund dankbar anerkennt; auch die Programme des Vereins lassen in erfreulicher Weise künstlerischen Fortschritt wahrnehmen. Der Verein brachte in seinem zweiten diesjährigen Concerte am 20. April unter Leitung von Dr. Ludwig Procházka für den Prager Dombaufond Schumann's Musik zu Byron's Manfred, das Schicksalslied von Brahms, eine musikalisch hochinteressante Wiedergabe des großartigen, in klassisch-hellenischem Geiste empfangenen Höderlin'schen Gedichtes Hyperions Schicksalslied, und Die Windsbraut Ballade für Soli, Chor und Orch. von Zdenko Fibich, die zwar einzelne gelungene Züge dramatischer Charakteristik enthält, aber Fülle musikalischer Begabung, Kraft und Mächtigkeit der Gestaltung, Eigenschaften, die zur Bewältigung einer so schwierigen Aufgabe erforderlich sind, durchaus vermissen läßt. Auch ist nicht zu begreifen, was Fibich dazu bewogen haben mag, seiner Composition eine so schwache böhmische Verarbeitung der gewaltigen, sprachlich vollendeten Kinkel'schen Ballade zum Grunde zu legen, ein Fehler, der sich an ihm gerächt hat." On a detailed account of Fibich's relationship with Jan Ludevít Procházka, who also was an important music critic in Prague, see Jana Vojtěšková, "Zdeněk Fibich, Jan Ludevít Procházka, and Early Performances of Fibich's Works," Musicologica Olomucensia 12 (December 2010): 141-150. 
the audience exhaustively, but the composer also lacks the elementary power of conception which would have been necessary to compete successfully with such a high-calibre work as that of Brahms, although 'Die Windsbraut' contains some felicitous onomatopoeic passages and some industrious work. [...] Furthermore, it is not beneficial to Gottfried Kinkel's poem that it was translated into Czech. Miss Sitt and the gentlemen Bavra and Czech sang the solo parts, but they seemed lost, because a great part of the exceptionally large audience had left the concert after the second number and those who remained were unable to enjoy the piece with attention, as they had already been exhausted by too much music. ${ }^{13}$

What emerges from these reviews is a distinct criticism of the Czech translation. Although the 1911 piano reduction was published with both the German and Czech words, the 1879 Prague performance obviously took place in Czech, which may certainly also point to socio-political moves within the context of Czech music programming in the second half of the nineteenth century. The Germanlanguage reviews offer no details on the actual faults they depict in the Czech translation, which makes it even more difficult to ascertain whether this criticism was in any way justified on the basis of linguistics or whether they were a mere reflection of contemporary cultural politics. It is not my place to dive deeply into a literary analysis of the two versions of the text, and considering that language changes constantly with time, my understanding of the Czech and German languages today would likely be of no benefit to such a linguistic analysis. In the light of the circumstances of the time, it is plausible that the two Germanlanguage reviewers cited here read the work with socio-politics in mind, thus perhaps unjustifiably rejecting Czech-language translations of German originals

13 "Concerte", Montags-Revue aus Böhmen: Wochenschrift für Politik, Volkswirtschaft, Kunst und Literatur 1, no. 4 (28 April 1879): 8. "Nach dieser Composition, zu deren Ehre wohl das Größte damit gesagt ist, daß sie neben dem vorangegangenen Manfredt ihre mächtige Wirkung ungeschwächt behauptete, hatte die dritte und letzte Nummer des Programmes, das Tongemälde die Windsbraut für Soli, Chor und Orchester von Zd. Fibich, einen sehr schweren Stand, nicht nur weil die Dauer der beiden frühen aufgeführten Tonwerke die Empfänglichkeit der Hörer bereits erschöpfend in Anspruch genommen hatte, sondern es dem Componisten auch, trotz manches gelungenen tonmalerischen Zuges und einer Summe tüchtiger Arbeit, die sich in seiner Composition ausspricht, doch an der elementaren Kraft der Conception fehlt, um sich mit einem so anspruchsvoll auftretenden Werke neben Brahms mit Erfolg behaupten zu können. Auch weniger ermüdete Zuhörer, als jede des Sonntagsconcerts bereits waren, würden aus der Windsbrautt schwerlich einen erquicklich klaren, präcis zu definierenden Eindruck gewinnen. Zudem war es auch dem Gedichte des Sprachkünstlers Gottfried Kinkel nicht förderlich, daß ihm behufs seiner Composition durch Herrn Fibich die Gewalt der Uebersetzung ins Czechische angethan wurde. Frl. Sitt, die Herren Bavra und Czech sangen in der Windsbrautt die Solopartien, wirkten jedoch auf verlorenem Posten, da von dem außerordentlich zahlreichen Publikum des Concerts ein großer Theil nach der zweiten Nummer nicht zu halten war, und die Bleibenden, von allzu viel Musik abgespannt, nicht mehr mit Empfänglichkeit zu genießen im Stande waren.” 
in general. The review in Dalibor supports this assumption by stating the opposite of what the German-language reviewers emphasised:

The composition originates from an earlier time, when Fibich, who is now known to be one of Smetana's most sincere followers, was still imprisoned with all his soul in the heart of the modern German music school. It is also a setting of an original German text, Windsbraut, by Kinkel; the Czech translation originates from J. S. Debrnov's proven feather in the field. ${ }^{14}$

Here, the Czech interpreter, Josef Srb-Debrnov, is praised as a leading figure of the time and Fibich's orientation towards his later compositional aesthetics reminiscent of those of Smetana are foregrounded. Nevertheless, it needs to be noted that the 1873 review in Dalibor cited above was quite enthusiastic about Fibich's equal positioning among his German predecessors. The German-language reviews of 1879 , on the other hand, suggest that Fibich's compositional aesthetics were inferior to those of Brahms, for instance. When interpreting these reviews, however, one should remember that all reports share a certain concern about the duration of the concert, an aspect which must have influenced the reception and performance of the last piece in the programme, which was Meluzina. Furthermore, like every human being, each reviewer is influenced heavily by their own tastes, expectations, and the habits and conventions surrounding them. Thus, while it is possible that the reviewers were right in so far as Fibich's Meluzina was aesthetically less challenging than large-scale works by Brahms or Schumann, for instance, this is not to say that it is culturally or, indeed, musichistorically less interesting.

Rather than dwelling on onomatopoeic features which were emphasised within both the German- and Czech-language discourses of the time, I want to draw your attention to Fibich's Meluzina's words and the context within which they were conceived, as well as its overall formal constellation and careful consideration of feminine agency. These overarching concepts remained unacknowledged by the reviewers of the time, although—or possibly even because-they suggest that the composition was, indeed, a quite complex and well-conceptualised work inviting musicological enquiry beyond socio-political issues and punctual aesthetics.

Fibich's ballad was published bilingually in German and Czech. While the German version is titled 'Die Windsbraut', it seems that either Fibich or the translator felt that a more commonly recognisable title might be more suitable,

${ }^{14}$ Dalibor 1, no. 14 (10 May 1879): 112. "Skladba ta pochází $\mathrm{z}$ oné dřívější doby, kdy Fibich, jenž nyní, jak známo, náleží k nejupřímnějším stoupencům Smetanovým, vězel ještě celou duší ve sféře moderní hudební školy německé. Jest komponována též na původní německý tekst Windsbraut od Kinkla; český překlad pochází z osvědčeného v oboru tom péra J. S. Debrnova.” 
thus deciding for the Czech title Meluzina. ${ }^{15}$ It should be noted that Gottfried Kinkel, in his poetry, at no point uses the word "Meluzína", but "Windsbraut", literally "the bride of the wind", which reflects the ballad's plot more accurately. ${ }^{16}$ Kinkel wrote the poem "Die Windsbraut' in 1841 within the context of the Maikäferbund, a private literary association founded in 1840 by Kinkel himself and his wife-to-be, the composer, music pedagogue and pianist Johanna Mathieux. ${ }^{17}$ Gottfried Kinkel's poem was published by the renowned German publisher Cotta in Kinkel's first bound volume of poems in 1843, the same year in which Gottfried and Johanna got married. ${ }^{18}$ The Maikäferbund was influenced by typical Romantic and Biedermeier sentiments associated with 1840s Germany. When individual members of the circle displayed an increased interest in politics in 1847, the association was closed, as not all participants shared the same political passions; Gottfried Kinkel, for instance, sided with the liberal movement, while others preferred to stay away from politics altogether. It is this context within which Gottfried Kinkel joined the democratic movement in Germany in 1848, and, in 1849, joined the revolutionaries on the battlefield, was injured and imprisoned. Kinkel's political activities were covered all over the German-speaking media. It was this occasion, which, too, gained the Kinkels their first mention in a Prague-based newspaper, Bohemia: Ein Unterhaltungsblatt für gebildete Stände, which acknowledged on May 29, 1849 that "the "Neue Bonner Zeitung" is currently being edited by a woman, Mrs Johanna Kinkel". ${ }^{19}$ Gottfried Kinkel had

15 The Maikäferbund was primarily a platform for a vivid exchange of ideas regarding literature, philosophy, art, and music. It embraced weekly gatherings in the German city of Bonn, in the Rhineland, at which shorter fictional and non-fictional texts were recited, conceived, and discussed; joint works were created among different members of the association; and time was passed playing literary games and riddles. Johanna Kinkel kept a handwritten journal of the group's activities. These journals were edited in the last century and include the literature that sprung out of the meetings (poems, anecdotes, short stories, essays, dramatic works, reports of joint journeys to the countryside), accompanied by drawings illustrating one of the themes covered in the corresponding number.

${ }^{16}$ For contemporary descriptions of the two myths, Melusine and Windsbraut, see: "Windsbraut", in Meyers Großes Konversations-Lexikon, Vol. 20 (Leipzig: Meyer, 1909), 670; and, for instance, "Melusine”, in Meyers Großes Konversations-Lexikon, Vol. 1 (Leipzig: Meyer, 1908), 584-5.

17 On the creative collaboration between Gottfried and Johanna Kinkel see, in chronological order, Monica Klaus, Johanna Kinkel: Romantik und Revolution (Cologne: Böhlau, 2008); Daniela Glahn, Johanna Kinkel: Bilder einer Autorschaft (München: Allitera, 2017); Anja Bunzel, The Songs of Johanna Kinkel: Genesis, Reception, Context (Woodbridge: Boydell, 2020).

18 Gottfried Kinkel, "Die Windsbraut," in Gedichte von Gottfried Kinkel (Stuttgart/Tübingen: Cotta, 1843), 32-36. For an edition of the Maikäfer journals, see Maikäfer: Zeitschrift für Nichtphilister, ed. Bettina Brand et al. (Bonn: 1991).

19 "Mosaik," Bohemia: Ein Unterhaltungsblatt für gebildete Stände 22, nos 126-127 (29 May 1849): no pagination. "[...] die Neue Bonner Zeitung wird gegenwärtig von einer Dame, von der Frau Johanna Kinkel redigiert”. 
transferred his editorial duties of the paper to his wife, who was equally involved in politics, albeit through other (non-physical) avenues. ${ }^{20}$

In 1873, when Fibich's setting of Gottfried Kinkel's poem was announced in Dalibor, Johanna Kinkel was dead for more than a decade- she died in 1858, and Gottfried Kinkel was acknowledged by literary historians primarily for his epic poem Otto der Schütz rather than his shorter poems and ballads. Nevertheless, Heinrich Kurz, in 1872, highlighted the Windsbraut as one of Kinkel's "successful ballads and legends [...] which is characterised by felicitous innovation and personification and a lively plot". ${ }^{21}$ There is currently no trace of Fibich and Kinkel having been in personal contact with each other, or of Fibich having been aware of the Kinkels' socio-political circumstances. ${ }^{22}$ It is thus likely that Fibich came across the published words during his manifold encounters with German literature and culture, and that the imaginary potential and the popular theme of Kinkel's Windsbraut drew Fibich's attention to the ballad. A brief synopsis: a giant's daughter is looking for a worthy husband. As she has gained bad experiences with earthly beings, she explicitly invites unearthly spirits to woo for her. Three attempts by the water, fire, and earth spirits remain unreciprocated. It is the air spirit which finally wins over the giant's daughter; together they leave for adventures all over the world and harm the humans, to whom the giant's daughter had sworn vengeance on account of her disappointments earlier in life. ${ }^{23}$ How does Fibich treat this plot?

Table 1 summarises harmonic and metric features of Fibich's Meluzina in response to the textual content of the individual sections.

${ }^{20}$ See Klaus, Johanna Kinkel, $98 \mathrm{ff}$.

${ }^{21}$ Heinrich Kurz, "Neueste Literatur, Poesie, Gottfried Kinkel," Geschichte der deutschen Literatur mit ausgewählten Stücken aus den Werken der vorzüglichsten Schriftsteller (Leipzig: Teubner, 1872), 419-22 (419). “Außer mehreren gelungenen Balladen und Legenden, Vol. 4 [...], unter denen sich namentlich ,Die Windsbraut' durch glückliche Erfindung, treffliche Personification und lebendigen Gang auszeichnet, hat Gottfried Kinkel eine einzige größere epische Dichtung [Otto der Schütz] verfaßt; aber diese sichert ihm eine ansehnliche Stelle unter den deutschen Epikern zu."

${ }^{22}$ There is no mention of Fibich in the Findbuch summarising all letters received by Kinkel, currently held at Universitäts- und Landesbibliothek Bonn. Accessed December 4, 2020, https://www.ulb. uni-bonn.de/de/sammlungen/nachlaesse/findbuecher-und-inhaltsverzeichnisse/kinkel [accessed 4 December 2020].

${ }^{23}$ The full text is available online at the Deutsche Gedichtebibliothek, accessed December 4, 2020, https://gedichte.xbib.de/Kinkel_gedicht_012.+Die+Windsbraut.htm. 


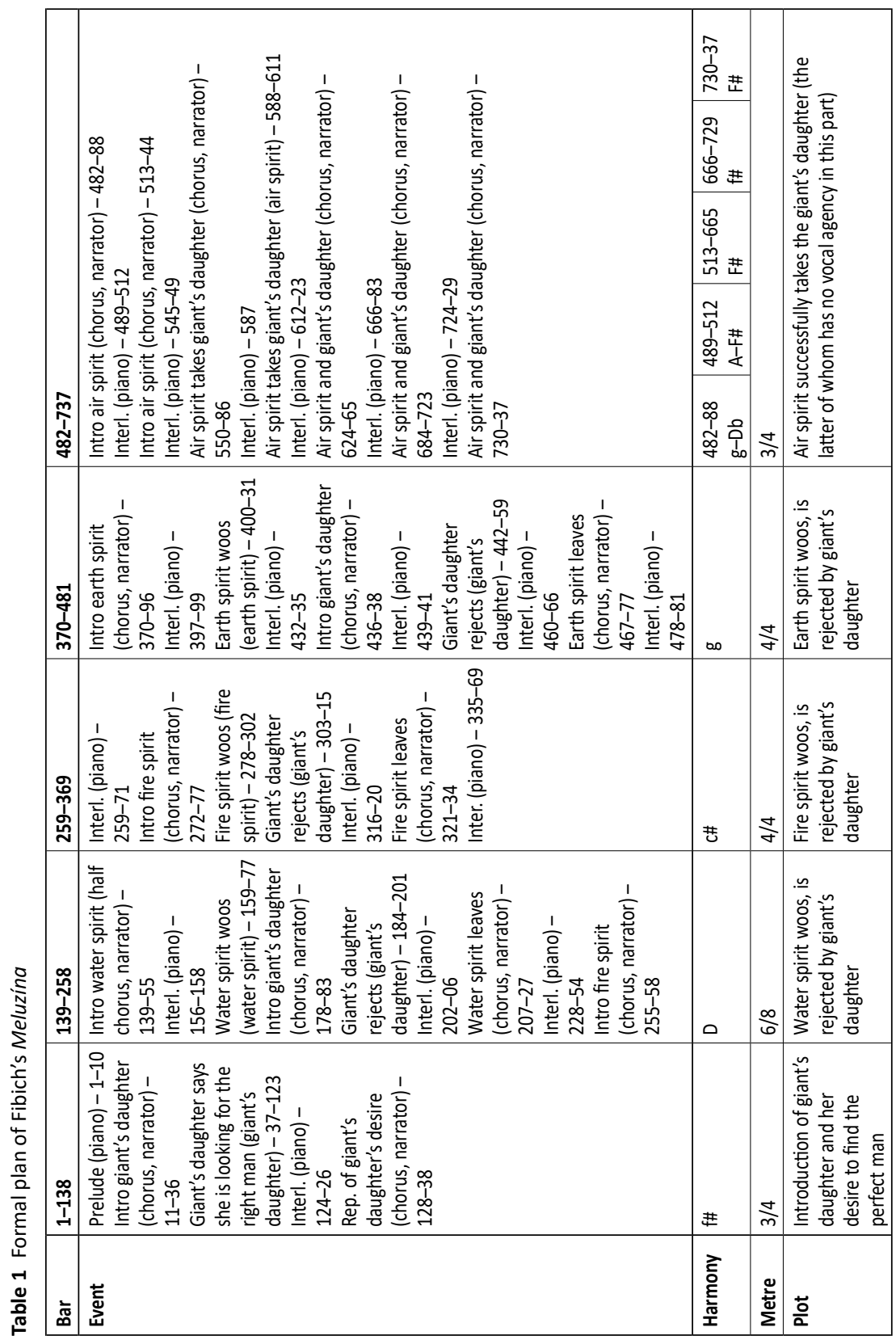


Here, it becomes obvious that each section of the plot is characterised by a different key: the giant's daughter is introduced in F-sharp minor; the water spirit operates in its lower mediant D major. Following on from that, the fire spirit's section is set in the initial tonic's dominant C-sharp minor, followed by the earth spirit's part in the remote key of $\mathrm{G}$ minor. Finally, the air spirit, which wins over the giant's daughter and takes her with him, is represented by F-sharp major, the major version of the initial tonic. Through this harmonic move, Fibich portrays the unity between the giant's daughter and the air spirit, as the giant's daughter's F-sharp minor now appears in its major mode. Furthermore, both outer sections include short allusions to the corresponding major (in bars 35-41, where the giant's daughter asks who will want to win her over) and minor modes (in bars 684-829, where the giant's daughter's and air spirit's joint activities are accounted for). Gottfried Kinkel, in his poem, does not give the giant's daughter any agency whatsoever in the last section. While in all other sections the giant's daughter rejects the courting spirits by herself, through her own voice, this last section is reproduced by both the narrator (taken on by the chorus) and the air spirit, respectively. By interweaving the mode of F-sharp minor into this section, Fibich thus grants the giant's daughter, i.e., Meluzína, a musical voice, subtly allowing her to enter the scene without saying anything.

In a similar way to the harmonic plan, the metre changes throughout the piece in accordance with the individual parts: the giant's daughter and the air spirit move in $3 / 4$, that is in triple metre, - again, note the unison, which allows Meluzína a personal, familiar note without taking the role of an active speaker. By contrast, the water spirit (in 6/8), the fire spirit (in 4/4), and the earth spirit (also 4/4), are all set in duple and quadruple metres, respectively.

Finally, Fibich uses distinct motives in order to portray the main characters. For instance, the giant's daughter is assigned a motif which introduces her and her search for a man right at the start (Example 1). It consists of a threestep ascent in quavers, c\#-f\#-b, followed by a stepwise descent comprising two semiquavers, $\mathrm{a}-\mathrm{g \#}$ and one quaver, $\mathrm{f \# ,} \mathrm{a} \mathrm{quaver} \mathrm{upward} \mathrm{leap} \mathrm{to} \mathrm{c \#}$, and in some instances, a concluding stepwise ascent to a minim, $\mathrm{b}$.

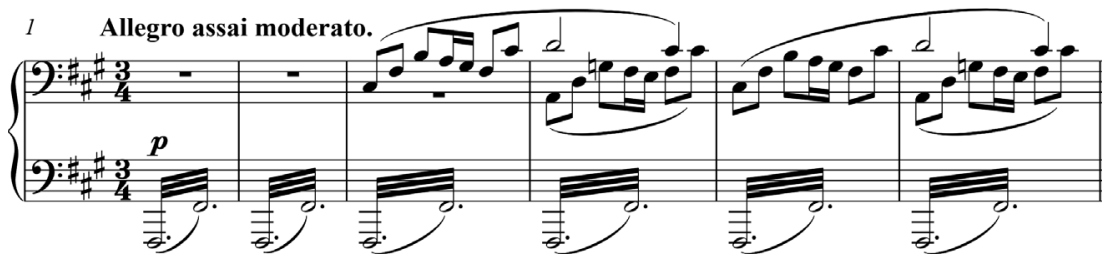

Example 1 Motif assigned to the giant's daughter in Fibich's Meluzína, piano prelude, bars 1-6 
This motif recurs in very slight variants throughout the first section of the piece (bars 1-138, see, for instance, Examples 2 and 3). These variations have been implemented primarily in order to accommodate and support harmonic progressions. Overall, however, the original motif makes by far the most frequent appearance.

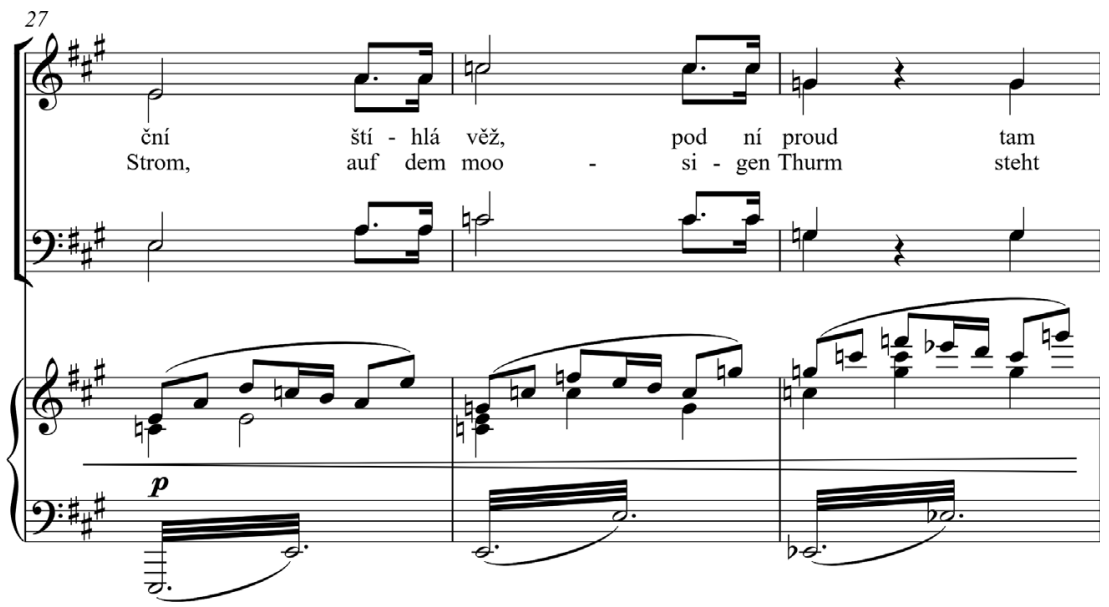

Example 2 Motif assigned to the giant's daughter recurring in the piano accompaniment in bars 27-29
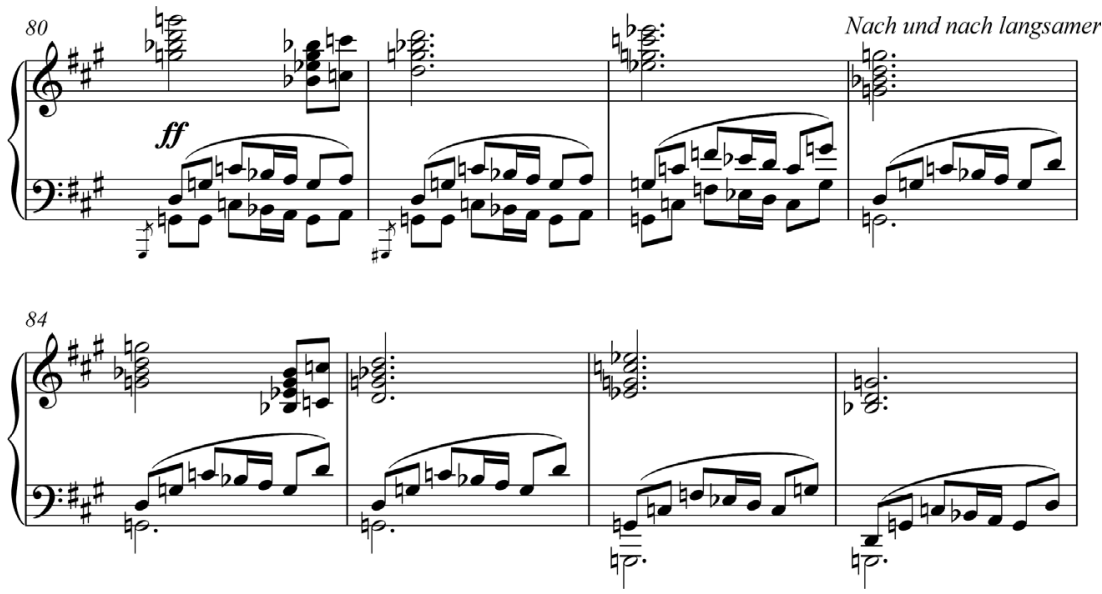

Example 3 Motif assigned to the giant's daughter recurring in the piano interlude, bars 80-87 
In the following sections, where other characters are foregrounded, this motif does not sound, but the general atmosphere reminiscent of the agitated giant's daughter is maintained by way of tremolos throughout all sections. It is in bar 674 that the listener immediately anticipates that the giant's daughter's search has been successful, as the initial motif recurs in its original form (Example 1). The only difference between those two occurrences lies in the motif's execution: the second time, in bar 674, it is to be played "at the same tempo as at the beginning, just a little faster" (Tempo wie zu Anfang, aber etwas rascher). Vladimír Hudec regrets that this motivic constellation brings the cantata to a "pathetic" conclusion. ${ }^{24}$ It might be true that, compared to other dramatic works of Fibich's, Meluzina is not quite as innovative, as the motivic reworkings are very modest and may seem a little blunt. However, it needs to be noted that it is through precisely these motives that Fibich lets Meluzína enter the scene in the last section, in which she has no active speech act. Thus, the compatibility between the air spirit and Meluzína, and the work's aesthetic organicity are supported by way of musical stylistic means, making Fibich's Meluzina an interesting dramatic work relying neither solely on visual components on the stage nor on literary hints in the words. Had Fibich reused the giant's daughter's motif less modestly throughout the entire piece, perhaps the effect of its recurrence in the final section would have been weaker.

To conclude, this essay sought to raise a number of points. First, although Gottfried Kinkel was known to the Prague press as early as 1849 , he received no attention as the poet of Fibich's Meluzina in the various reviews of Fibich's work. Rather, he was mentioned in passing and the translation by Josef Srb-Debrnov was foregrounded in one of the reviews. Nevertheless, and despite the political climate of the time, the Bohemian press considered Fibich within a European, or at least, Austro-German context, by comparing Fibich with Mendelssohn, Schubert, and Schumann (especially in the early review dated 1873). On the other hand, the slightly later review cited here (dated 1879) made clear that Fibich's later orientation towards Bedřich Smetana rather than towards his German contemporaries was a positive development within Fibich's compositional thinking. Second, the Neue Zeitschrift für Musik reported on the performance of Fibich's work in Prague when other German composers, namely Schumann and Brahms, were programmed alongside Fibich; likewise, the German-language Bohemian journal Montags-Revue aus Böbmen. These two reviews are focused more on the words and the criticism of the Czech translation than the ones published in the Czech-language press, a phenomenon which may be explained through the

24 “patetická poloha”; Vladimír Hudec, Zdeněk Fibich (Prague: SPN, 1971), 28. 'patetická poloha' 
socio-political circumstances surrounding the areas of performance practice and music criticism. Third, it seems that Fibich's reputation as a dramatic composer was established already in the 1870s, as the reviews, if/when they covered some small amount of detail on the music, focused on punctual musical interpretations of dramatic aspects. The reviewers did not comment on larger conceptual matters, even though this composition, as my short analysis has shown, would have been suitable to promote Fibich's compositional farsightedness and his aesthetic nuances (for instance, his way of giving the main protagonist agency when she was not given a voice in the original poem).

Time and space have not been sufficient to look at other-most intriguing-music-analytical or contextual aspects surrounding Fibich's Meluzina, for instance possible aesthetic intersections and parallels between this large-scale vocal piece and Fibich's songs, or the question why it was published in 1911 with piano accompaniment rather than as an orchestral work, which it was originally. It is likely that performance possibilities and economic aspects played a role here, as a pianistic performance would have been easier to accomplish than an orchestral one, thus promising better sales of the score..$^{25}$ One should think that the existence of a piano version would enable performances and recordings more easily also today. Despite or perhaps because of its aesthetic modesty and less pompous setting, which comes naturally with a piano reduction, Meluzina is worthwhile performing on account of its general theme and subject matter, its interesting overall form, and its ability to add another layer to our picture of Fibich as a composer who catered for different aesthetic demands and performance contexts. Thus, perhaps this article will help to keep the momentum in exploring Fibich's compositional aesthetics through the analysis of music and text, as well as through the lens of the international contemporary reception of those works of Fibich's which were not primarily written for the stage.

${ }_{25}$ This idea corresponds with Jana Gajdošíková's observations of the publisher Urbánek having been the most prolific publisher of salonesque music, i.e., music intended for performance in smaller gatherings with more modest financial means, during the second half of the nineteenth century. Jana Gajdošíková, "European and Czech Salon Piano Music in the Second Half of the 19th Century," Musicologica Olomucensia 12 (December 2010): 95-100 (97). 


\title{
"...which, like his latest songs, might extend his name also within the wider circles of the artistic world": Zdeněk Fibich's Meluzína (op. 55 Hud. 187)
}

\begin{abstract}
On January 10,1873, the journal Dalibor predicted for Zdeněk Fibich's Meluzina that its success would help to spread Fibich's name within the 'wider circles of the artistic world'. In retrospect, this prediction might have been a little too optimistic, as, up until this day, Fibich has been acknowledged primarily for his innovative approach to music-dramatic genres. This paper aims to close this research lacuna by shedding light on both Meluzina's reception and selected compositional-aesthetic features.
\end{abstract}

\section{“...kteráž jako nejnovější jeho písně, jméno jeho rozšířiti může i v širších kruzích světa uměleckého": Meluzína Zdeňka Fibicha (op. 55 Hud. 187)}

\section{Abstrakt}

Článek z 10. ledna 1873 otištěný v Daliboru predikoval, že úspěch Meluziny Zdeňka Fibicha napomůže šíření Fibichova jména v „širších kruzích uměleckého světa“. Tato predikce byla, zpětně vzato, možná až přiliš optimistická, protože Fibich je až do současnosti oceňován převážně pro svioj inovativní př́stup $\mathrm{k}$ hudebně-dramatickému žánru. Př́ispěvek se zaměřuje na osvětlení dosud opomíjené oblasti bádání a zkoumá recepci a některé kompozičně estetické aspekty Meluziny.

\section{Keywords}

Zdeněk Fibich; Meluzina; vocal music; Fibich reception in Europe; gender and music

\section{Klíčová slova}

Zdeněk Fibich; Meluzina; vokální hudba; recepce Fibicha v Evropě; genderové studie a hudba

Anja Bunzel

Institute of Art History, Czech Academy of Sciences

bunzel@udu.cas.cz 